\title{
Sistem Pakar Berbasis Android untuk Diagnosis Diabetes Melitus dengan Metode Forward Chaining
}

\author{
Devi Astri Nawangnugraeni* \\ Program Studi Teknologi Komputer, Fakultas Sains dan Teknologi, Institut Teknologi dan Sains Nahdlatul \\ Ulama Pekalongan \\ Jl. Karangdowo No. 9, Pekalongan, Indonesia 51173 \\ *devinawang4@gmail.com
}

(Naskah masuk: 27 Agustus 2020; diterima untuk diterbitkan: 11 Nopember 2020)

\begin{abstract}
ABSTRAK - Diabetes Melitus termasuk salah satu penyakit berbahaya yang disebabkan kurangnya pengetahuan masyarakat mengenai gejala penyakit yang ditimbulkan. Artikel ini menyajikan pengembangan aplikasi sistem pakar yang digunakan sebagai perangkat diagnosis diabetes melitus pada mobile android. Tujuan aplikasi ini untuk mendeteksi diabetes melitus berdasakan gejala yang sedang dialami oleh seseorang sesuai dengan tipe penyakit diabetes melitus dan menentukan persentase kemungkinan terjadinya penyakit tersebut. Dalam pengembangkan aplikasi sistem pakar ini menggunakan metode forward chaining. Penerapan metode forward chaining digunakan untuk mengumpulkan informasi kemudian dilanjutkan dengan mengimplementasikan penalaran dengan aturan ifthen sebagai hasil kesimpulan diagnosis sesuai dengan gejala. Tahapan dalam pengembangan aplikasi sistem pakar ini menggunakan Expert System Development Life Cycle (ESDLC). Hasil pengembangannya yaitu sistem pakar yang digunakan untuk diagnosis penyakit diabetes melitus sesuai gejala yang diimplementasikan pada mobile android. Sistem pakar diujikan pada pakar yaitu Dokter Spesialis Penyakit Dalam untuk validasi aturan produksi diagnosis penyakit dengan hasil akurasi sistem $86,67 \%$. Hasil tersebut menyatakan bahwa sistem diagnosis penyakit diabetes melitus pada pasien sudah sesuai alur rekomendasi pakar sehingga sistem pakar tersebut termasuk baik sesuai dengan logika pakar.
\end{abstract}

Kata Kunci - Android; Diabetes Melitus; Diagnosis; Forward chaining; Sistem pakar.

\section{Diabetes Mellitus Diagnosing by Android Based Expert System using Forward Chaining Method}

\begin{abstract}
Diabetes mellitus is a dangerous disease caused by the lack of public knowledge about the symptoms of the disease. This article presents the development an expert system application for diabetes mellitus diagnose on android mobile. The purpose of application is to detect diabetes mellitus based on the type of diabetes mellitus symptoms and determine the possibility of the disease occurred. The method for developing an expert system is forward chaining. The implementation of forward chaining method is used to collect information then proceed by applying reasoning with if-then rule as a result of the conclusion of a diagnosis according to symptoms. The stages in developing this expert system application use the Expert System Development Life Cycle (ESDLC). The result of development is an expert system for diagnose diabetes mellitus according to the symptoms implemented on android mobile. The expert system was tested by internist to validate the rule base for disease diagnose with a system accuracy $86.67 \%$. This result indicate that the diagnose system for diabetes mellitus in patients is accordance with the flow of expert recommendations so the expert system is considered good according to expert logic.
\end{abstract}

Keywords - Android; Diabetes Mellitus; Diagnose; Forward chaining; Expert system.

\section{Pendahuluan}

Diabetes Melitus (DM) termasuk salah satu gangguan metabolisme yang dihasilkan dari cacat pada sekresi insulin dan/atau tindakan insulin yang menghasilkan hiperglikemia dengan gangguan 
karbohidrat, lemak dan protein metabolisme [1]. Jumlah penderita diabetes melitus di Indonesia berdasarkan perkiraan WHO dalam PERKENI akan mengalami kenaikan setiap tahunnya [2]. Gejala diabetes melitus ini dapat berkembang secara cepat apabila gejala awal tidak diketahui. Namun pada kondisi diabetes melitus tipe 2 umumnya tidak terlihat gejala secara spesifik bahkan diketahui setelah mengalami diabetes melitus yang sudah parah [3]. Selain itu keterlambatan pengecekan dan penanganan dapat menimbulkan komplikasi kronik diabetes melitus atau disebut sebagai diabetes nefropathy.

Gejala nefropathy dapat mengakibatkan pasien mengalami gagal ginjal. Sehingga untuk mencegah terjadinya komplikasi harus dilakukan deteksi sedini mungkin dan melaksanakan penatalaksanaan yang komprehensif berupa penurunan berat badan atau perubahan gaya hidup dan pemberian obat [4]. Dengan melaksanakan tata laksana tersebut bertujuan untuk menurunkan gula dalam urin menjadi negatif sehingga dapat mengurangi resiko komplikasi diabetes melitus [5], mencapai berat badan normal dan status gizi optimal [6], serta dapat melakukan pekerjaan dan aktivitas seperti biasa [7].

Pengecekan awal untuk diagnosis penyakit diabetes melitus tersebut dapat dilakukan dengan bantuan sistem pakar [8]. Implementasi sistem pakar ini digunakan sebagai penyimpanan pengetahuan pakar dalam program komputer sehingga keputusan dapat diberikan dengan penalaran yang cerdas.

Salah satu penerapan sistem pakar untuk diagnosis penyakit diabetes melitus yaitu sistem dengan fungsi indikator kesehatan berbasis aturan. Dalam sistem pakar tersebut fungsi basis aturan disederhanakan menggunakan metode fungsi logika Boolean [9]. Selain itu sistem pakar diagnosis penyakit diabetes melitus juga dapat dianalisis menggunakan metode forward chaining. Metode forward chaining digunakan untuk mencari atau melacak informasi secara maju dan menggabungkan aturan-aturan untuk menghasilkan suatu kesimpulan dan tujuan diagnosis yang logis $[10,11]$.

Pengembangan sistem pakar dapat diterapkan pada sebuah mobile. Salah satunya yaitu pemanfaatan mobile untuk manajemen kendali-diri pada pasien diabetes melitus [12]. Penggunaan aplikasi mobile saat ini dapat diimplementasikan diberbagai platform seperti android, Windows Phone maupun iOS. Aplikasi mobile dengan sistem operasi android telah dikembangkan sebagai perangkat kendali kesehatan [13]. Selain itu juga terdapat aplikasi pada mobile berbasis android yang digunakan sebagai perangkat untuk diagnosis, kontrol dan monitoring kesehatan
$[14,15]$.

Berdasarkan penelitian sebelumnya kemampuan yang tepat dalam menganalisis gejala merupakan hal yang penting dalam melakukan pencegahan diabetes melitus. Oleh karena itu deteksi dini penyakit diabetes melitus sangat diperlukan. Sebagai pengecekan awal dapat dilakukan dengan bantuan sistem pakar. Maka dikembangkan sebuah aplikasi sistem pakar pada perangkat bergerak yang dapat berjalan pada sistem operasi android sebagai aplikasi diagnosis penyakit diabetes melitus. Sistem ini diimplementasikan pada pasien diabetes melitus menggunakan metode forward chaining.

\section{METODE DAN BAHAN}

\subsection{Metode}

Pengembangan sistem pakar ini menggunakan metode yang secara khusus diterapkan dalam pengembangan sistem pakar yaitu Expert System Development Life Cycle (ESDLC). Adapun tahapannya yaitu identifikasi masalah, pengembangan sistem (pembuatan konsep, formalisasi, implementasi, pengujian), transfer produksi, dan operasi (pemeliharaan sistem dan evaluasi sistem). Tahapan pengembangan sistem dapat dilihat pada Gambar 1 [16].

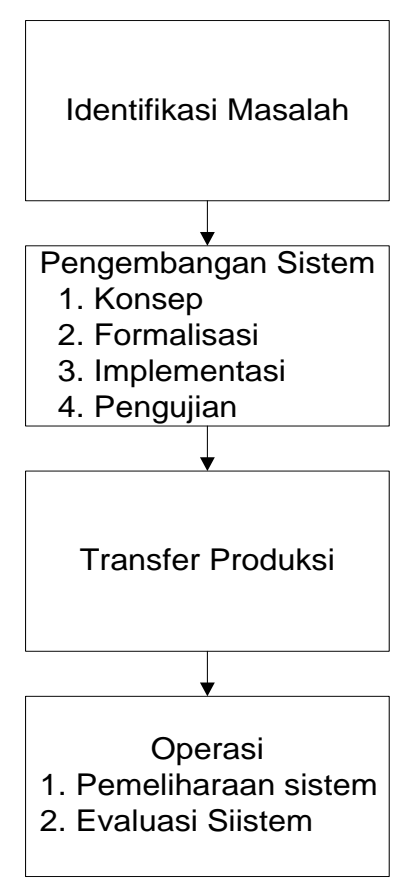

Gambar 1. Tahapan pengembangan sistem pakar

Tahap yang pertama adalah identifikasi masalah yaitu menjelaskan permasalahan atau kebutuhan yang menjadi objek yang dinilai. Selain itu menetapkan tujuan pengembangan sistem pakar dan mengidentifikasi metode yang digunakan untuk 
penarikan kesimpulan pada sistem pakar. Objek pada pengembangan sistem pakar adalah penyakit diabetes melitus. Tujuan dalam penelitian ini yaitu mengembangkan sebuah sistem pakar untuk mendiagnosis penyakit diabetes melitus sesuai dengan tipenya dan menghitung persentase kemungkinan penyakit tesebut. Pada tahap identifikasi masalah juga ditentukan metode yang digunakan untuk menentukan kesimpulan. Dalam hal ini kesimpulan diagnosis penyakit diabetes melitus dianalisis menggunakan metode forward chaining, dan untuk menentukan persentase kemungkinan penyakit ditentukan menggunakan persamaan probabilistik klasik.

Tahap yang kedua yaitu melakukan pengembangan sistem yang dilakukan dengan mendeskripsikan konsep masalah, formalisasi, implementasi dan pengujian. Tahap konsep masalah yaitu mengidentifikasi sub-masalah, fitur sistem, dan kelayakan sistem yang dilakukan dengan pakar. Tahap formalisasi yaitu mengidentifikasi pengetahuan pada pakar yang dapat dilakukan dengan wawancara atau analisis. Hasil wawancara tersebut dijadikan aturan produksi dengan bentuk If [Parameter] Then [Parameter]. Tahap implementasi yaitu penerjemahan dari konsep aturan produksi ke dalam bahasa pemrograman. Apabila tahap pengembangan sistem sudah selesai maka dilanjutkan pada tahap pengujian yaitu verifikasi sistem pakar yang telah dikembangkan dan dengan menghitung akurasi sistem [18]. Sistem pakar diujikan kepada 15 responden kemudian dicocokkan dengan pakar untuk memaatikan akurasi aturan produksinya.

Setelah tahap pengembangan sistem dan diujikan kepada pakar, tahap selanjutnya yaitu memperbanyak produksi sistem pakar. Produksi tersebut bertujuan untuk membuat cadangan sistem pakar apabila terjadi kerusakan atau pembaharuan. Hal ini meliputi membuat cadangan basis data dan keamanan data pengetahuan pakar.

Tahapan yang terakhir yaitu operasi yang meliputi pemeliharaan dan evaluasi sistem pakar. Pemeliharaan dan evaluasi sistem pakar yaitu dengan mengatasi kesalahan atau kerusakan pada sistem pakar. Selain itu apabila terdapat pembaharuan pengetahuan maka sistem dapat dilakukan perbaikan kembali secara berkala.

\subsection{Bahan}

Bahan yang digunakan dalam aplikasi sistem pakar ini yaitu data jenis kelamin, berat badan, tinggi badan, usia, dan gejala komplikasi diabetes melitus. Data berupa data primer yang didapatkan dari wawancara pakar yaitu dengan Dokter Spesialis
Penyakit Dalam pada Rumah Sakit Umum Daerah M. Ashari Kabupaten Pemalang. Data yang diperoleh yaitu tipe penyakit diabetes melitus dan gejala yang diterapkan sebagai aturan "if-then" untuk ditarik kesimpulan logis sebagai hasil diagnosis penyakit. Adapun data tipe penyakit diabetes melitus dan gejala ditampilkan pada Tabel 1.

Tabel 1. Tanda dan gejala penyakit

\begin{tabular}{|c|c|}
\hline $\begin{array}{c}\text { Nama } \\
\text { Penyakit }\end{array}$ & Tanda dan Gejala \\
\hline $\begin{array}{l}\text { Diabetes } \\
\text { melitus tipe } \\
1\end{array}$ & $\begin{array}{l}\text { 1. Sering haus } \\
\text { 2. Sering lapar } \\
\text { 3. Sering kencing lebih dari } 8 \text { kali } \\
\text { sehari } \\
\text { 4. Penurunan berat badan } \\
\text { 5. Rasa lelah } \\
\text { 6. Mata kabur } \\
\text { 7. Kesemutan } \\
\text { 8. Gatal-gatal seluruh tubuh } \\
\text { tanpa sebab } \\
\text { 9. Timbul bisul yang bernanah } \\
\text { 10. Impotensi (L)/ keputihan (P) } \\
\text { 11. Infeksi } \\
\text { 12. Keturunan keluarga diabetes } \\
\text { 13. Usia antara } 0-14 \text { tahun }\end{array}$ \\
\hline $\begin{array}{l}\text { Diabetes } \\
\text { melitus } \\
\text { gestasional }\end{array}$ & $\begin{array}{ll}\text { 1. } & \text { Sering haus } \\
\text { 2. Sering lapar } \\
\text { 3. Sering kencing lebih dari } 8 \text { kali } \\
\text { sehari } \\
\text { 4. Penurunan berat badan } \\
\text { 5. Masa kehamilan } \\
\text { 6. Peningkatan kadar gula pada } \\
\text { masa kehamilan riwayat } \\
\text { 7. Mempunyai melahirkan bayi besar } \\
\text { 8. Mukosa bibir kering } \\
\text { 9. Mudah lelah } \\
\text { 10. Mata kabur } \\
\text { 11. Keputihan }\end{array}$ \\
\hline $\begin{array}{l}\text { Diabetes } \\
\text { melitus tipe } \\
2\end{array}$ & $\begin{array}{l}\text { 1. Sering haus } \\
\text { 2. Sering lapar } \\
\text { 3. Sering kencing lebih dari } 8 \text { kali } \\
\text { sehari } \\
\text { 4. Penurunan berat badan } \\
\text { 5. Keturunan keluarga diabetes } \\
\text { melitus } \\
\text { 6. Mudah lelah } \\
\text { 7. Mata Kabur } \\
\text { 8. Kesemutan } \\
\text { 9. Gatal-gatal seluruh tubuh } \\
\text { tanpa sebab } \\
\text { 10. Timbul bisul yang bernanah } \\
\text { 11. Impotensi (L)/ keputihan }(\mathrm{P}) \\
\text { 12. Infeksi }\end{array}$ \\
\hline
\end{tabular}




\begin{tabular}{lll} 
Diabetes & 1. & Sering haus \\
melitus tipe & 2. & Sering lapar \\
lain & 3. & Sering kencing lebih dari 8 kali \\
& sehari & \\
& 4. & Sering konsumsi obat steroid, \\
& seperti obat untuk \\
& peradangan, astma atau \\
& rheumatic & \\
5. & Infeksi \\
\hline
\end{tabular}

Kumpulan gejala-gejala yang ditunjukkan pada Tabel 1 dapat diidentifikasi sebagai pengetahuan pakar untuk menentukan diagnosis penyakit diabetes melitus. Hal tersebut dilakukan dengan diberikan kode untuk menentukan tabel keputusan yang terlihat pada Tabel 2.

Tabel 2. Kode gejala diabetes melitus

\begin{tabular}{|c|c|}
\hline $\begin{array}{l}\text { Kode } \\
\text { Gejala }\end{array}$ & Gejala \\
\hline G-01 & Sering haus \\
\hline G-02 & Sering lapar \\
\hline G-03 & Sering kencing lebih dari 8 kali sehari \\
\hline G-04 & Penurunan berat badan \\
\hline G-05 & Usia antara 0-14 tahun \\
\hline G-06 & Mudah lelah \\
\hline G-07 & Mata kabur \\
\hline G-08 & Kesemutan \\
\hline G-09 & Gatal-gatal seluruh tubuh tanpa sebab \\
\hline G-10 & Timbul bisul yang bernanah \\
\hline G-11 & Impotensi (L)/ keputihan $(\mathrm{P})$ \\
\hline G-12 & Infeksi \\
\hline G-13 & Keturunan keluarga diabetes melitus \\
\hline G-14 & Masa kehamilan \\
\hline G-15 & $\begin{array}{l}\text { Peningkatan kadar gula pada masa } \\
\text { kehamilan }\end{array}$ \\
\hline G-16 & $\begin{array}{l}\text { Mempunyai riwayat melahirkan bayi } \\
\text { besar }\end{array}$ \\
\hline G-17 & Mukosa bibir kering \\
\hline G-18 & Keputihan \\
\hline G-19 & $\begin{array}{l}\text { Sering konsumsi obat steroid seperti } \\
\text { obat untuk peradangan, astma, atau } \\
\text { rheumatik }\end{array}$ \\
\hline
\end{tabular}

Setelah diberikan kode pada gejala penyakit maka dilajutkan dengan membuat tabel keputusan untuk mendiagnosis penyakit diabetes melitus dan tabel aturan produksi. Tabel keputusan ditampilkan pada Tabel 3 dan tabel aturan produksi ditampilkan pada Tabel 4.
Tabel 3. Tabel keputusan

\begin{tabular}{ccccc}
\hline Kode & \multicolumn{5}{c}{ Kode Penyakit } \\
\cline { 2 - 5 } Gejala & P01 & P02 & P03 & P04 \\
\hline G-01 & $*$ & $*$ & $*$ & $*$ \\
G-02 & $*$ & $*$ & $*$ & $*$ \\
G-03 & $*$ & $*$ & $*$ & $*$ \\
G-04 & $*$ & $*$ & $*$ & \\
G-05 & $*$ & & & \\
G-06 & $\sqrt{ }$ & $\sqrt{ }$ & $\sqrt{ }$ & \\
G-07 & $\sqrt{ }$ & $\sqrt{ }$ & $\sqrt{ }$ & \\
G-08 & $\sqrt{ }$ & & $\sqrt{ }$ & \\
G-09 & $\sqrt{ }$ & & $\sqrt{ }$ & \\
G-10 & $\sqrt{ }$ & & $\sqrt{ }$ & \\
G-11 & $\sqrt{ }$ & & $\sqrt{ }$ & $\sqrt{ }$ \\
G-12 & $\sqrt{ }$ & & $\sqrt{ }$ & \\
G-13 & $\sqrt{ }$ & & $*$ & \\
G-14 & & $*$ & & \\
G-15 & & $*$ & & \\
G-16 & & $\sqrt{ }$ & & \\
G-17 & & $\sqrt{ }$ & & \\
G-18 & & $\sqrt{ }$ & & $*$ \\
G-19 & & & & \\
\hline
\end{tabular}

Keterangan:

P01 : Diabetes melitus tipe 1

P02 : Diabetes melitus gestasional

P03 : Diabetes melitus tipe 2

P04 : Diabetes melitus tipe lain

* : : Gejala yang harus dipilih

$\sqrt{ }$ : Gejala yang tidak harus dipilih

Tabel 4. Aturan produksi

\begin{tabular}{ll}
\hline Penyakit & \multicolumn{1}{c}{$\begin{array}{c}\text { Aturan } \\
\text { Produksi }\end{array}$} \\
\hline R1 & IF G-01 AND G-02 AND G-03 \\
& AND G-04 AND G-05 AND G-06 \\
& AND G-07 AND G-08 AND G-09 \\
& AND G-10 AND G-11 AND G-12 \\
& AND G-13 THEN P01 \\
R2 & IF G-01 AND G-02 AND G-03 \\
& AND G-04 AND G-14 AND G-15 \\
& AND G-16 AND G-17 AND G-06 \\
& AND G-07 AND G-18 THEN P02 \\
R3 & IF G-01 AND G-02 AND G-03 \\
& AND G-04 AND G-13 AND G-06 \\
& AND G-07 AND G-08 AND G-09 \\
& AND G-10 AND G-11 AND G-12 \\
R4 & THEN P03 \\
& IF G-01 AND G-02 AND G-03 \\
& AND G-19 AND G-12 THEN P04 \\
\hline
\end{tabular}


Untuk menentukan persentase kemungkinan penyakit diabetes melitus ditentukan pada persamaan 1. Persamaan 1 menunjukkan bahwa $P(G)$ adalah persentase peluang gangguan yang didapatkan dari pembagian jumlah gejala yang dipilih pengguna dan jumlah keseluruhan gejala terjadinya penyakit.

$$
P(G)=\frac{n}{N} \times 100 \%
$$

Sistem pakar akan diuji akurasinya dengan menggunakan persamaan 2 [17].

$$
\text { Nilai akurasi }=\frac{\text { Jumlah data akurat }}{\text { Jumlah seluruh data }} \times 100 \%
$$

Alat yang digunakan dalam pengembangan sistem pakar ini yaitu perangkat komputer dengan spesifikasi Processor core i3, memori 6GB, Harddisk 500GB dan aplikasi pendukung Android Studio.

\section{HASIL DAN PEMBAHASAN}

Hasil pengembangan sistem pakar ini dihasilkan sebuah aplikasi mobile berbasis android yang digunakan untuk diagnosis penyakit diabetes melitus sesuai dengan gejala yang terjadi pada seseorang. Sistem pakar ini terdiri atas halaman pembuka, halaman utama, menu Cek DM, menu Info $\mathrm{DM}$, dan menu tentang pengembang sistem.

Halaman awal pada sistem berupa tampilan splash screen yang muncul beberapa detik kemudian menuju ke halaman berikutnya. Pada halaman ini terdiri atas logo sistem dan nama sistem. Nama aplikasi ini adalah Sistem Pakar DM. Tampilan antarmuka pada halaman awal ditunjukkan pada gambar 2.

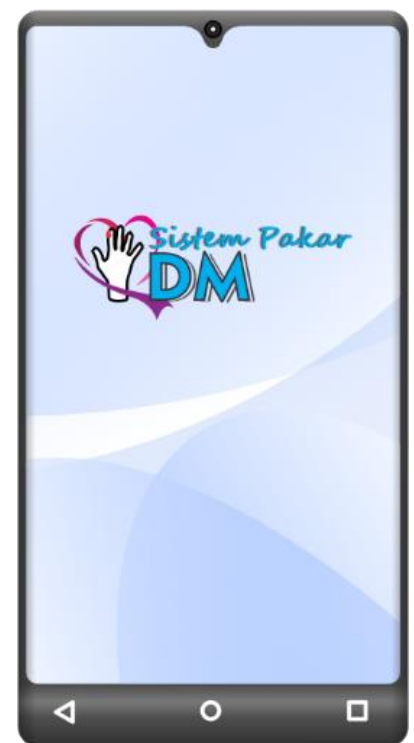

Gambar 2. Tampilan antarmuka halaman awal
Halaman utama berupa tampilan halaman sistem yang terdiri atas tiga menu utama. Tampilan halaman ini berupa tombol bergambar yang digunakan untuk menuju ke halaman menu cek DM, menu info DM, dan menu tentang pengembang sistem. Tampilan halaman utama ditunjukkan pada gambar 3.

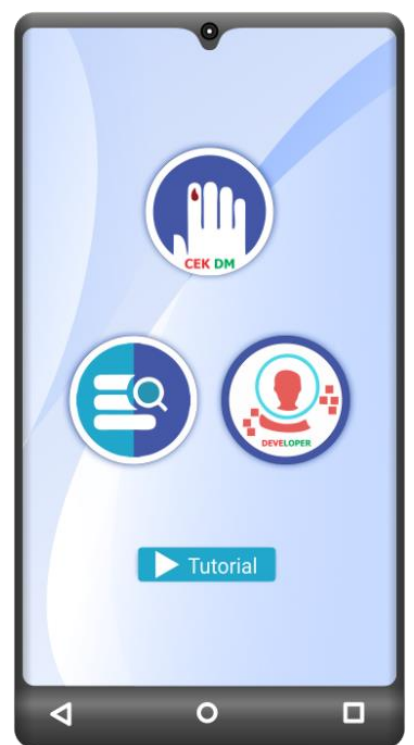

Gambar 3. Tampilan antarmuka halaman utama

Selain tiga menu pada halaman utama terdapat tombol Tutorial yang digunakan untuk menuju ke halaman tutorial. Halaman tutorial berupa tampilan halaman sistem yang digunakan untuk menampilkan informasi cara penggunaan sistem. Halaman ini ditampilkan dengan menekan tombol Tutorial pada sistem. Tampilan antarmuka pada halaman tutorial ditunjukkan pada Gambar 4.

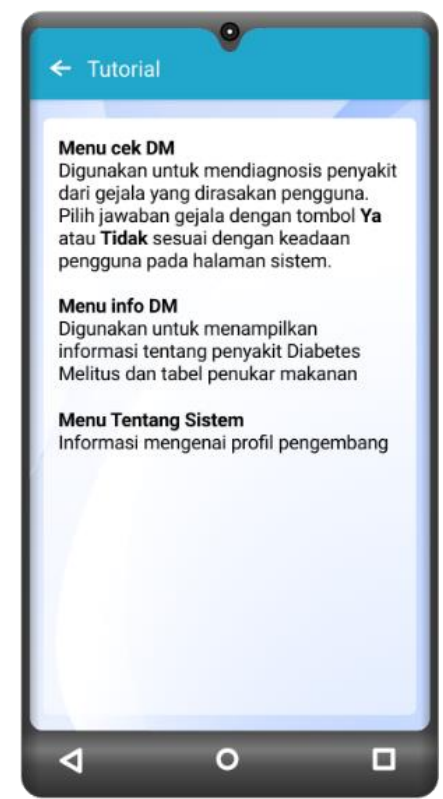

Gambar 4. Tampilan antarmuka halaman tutorial 
Menu Cek DM berupa tampilan halaman sistem yang digunakan untuk diagnosis diabetes melitus sesuai gejala yang terjadi pada pasien. Menu ini terdiri atas halaman untuk mengisi nama pengguna, jenis kelamin, dan halaman untuk memilih gejala penyakit yang dialami oleh pengguna. Pada sistem akan ditampilkan kolom untuk mengisikan nama dan jenis kelamin kemudian dengan menekan tombol Next sistem akan menampilkan pertanyaan gejala penyakit diabetes melitus sesuai dengan tipenya yaitu tipe diabetes melitus tipe 1 , diabetes melitus tipe 2, diabetes melitus tipe gestasional atau diabetes melitus tipe lain. Pengguna hanya mengisikan jawaban dari pertanyaan gejala dengan menekan tombol jawaban Ya atau Tidak. Antarmuka halaman cek DM ditunjukkan pada Gambar 5.

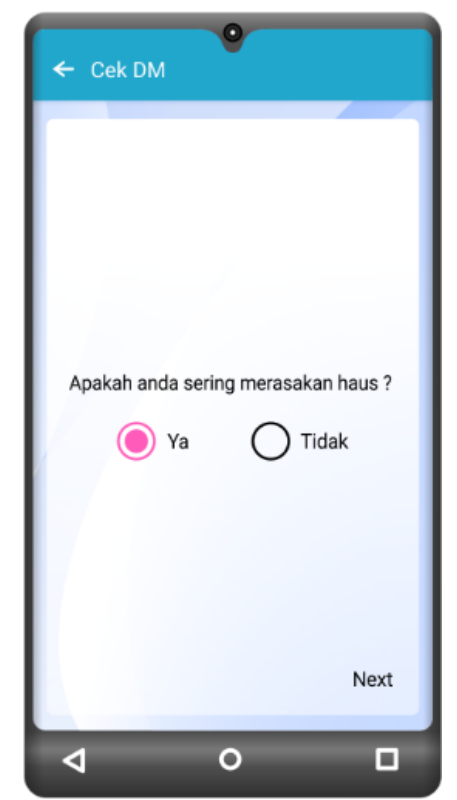

Gambar 5. Tampilan antarmuka halaman cek DM

Jawaban dari pengguna akan dihitung menggunakan persamaan 1 untuk menghitung persentase kemungkinan penyakit tersebut terjadi sesuai dengan gejala yang dialami oleh penggguna. Hasil diagnosis yang ditampilkan pada halaman sistem yaitu nama, jenis kelamin, jawaban yang dipilih pengguna, dan hasil perhitungan persentase kemungkinan penyakit. Antarmuka halaman antarmuka Hasil Cek DM ditunjukkan pada Gambar 6.

Menu Info DM berupa tampilan halaman sistem yang digunakan untuk menampilkan informasi mengenai penyakit diabetes melitus, konsep diet diabetes melitus, dan tabel penukar makanan. Pada sistem ditampilkan informasi mengenai penyakit diabetes melitus kemudian dilanjutkan dengan tabel penukar makanan. Informasi mengenai penyakit diabetes melitus dan konsep diet diabetes melitus ditampilkan dalam satu antarmuka halaman pada sistem, sedangkan tabel penukar makanan ditampilkan pada halaman sistem selanjutnya. Antarmuka halaman info DM ditunjukkan pada Gambar 7.

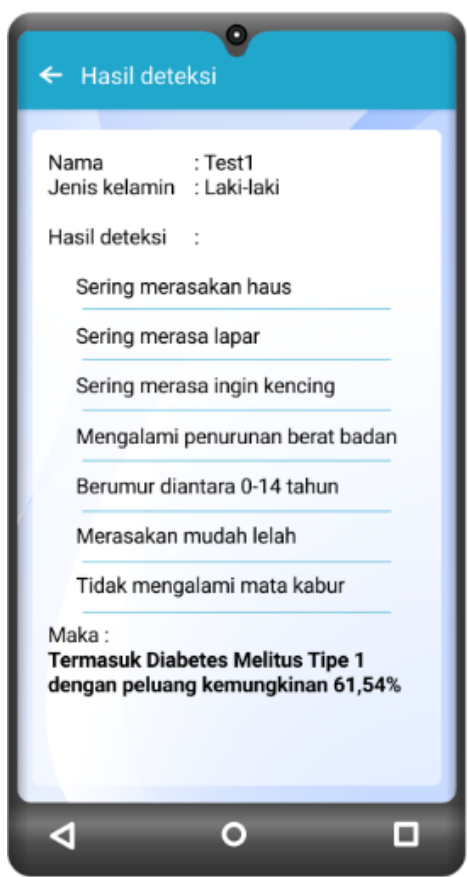

Gambar 6. Tampilan antarmuka halaman hasil Cek DM

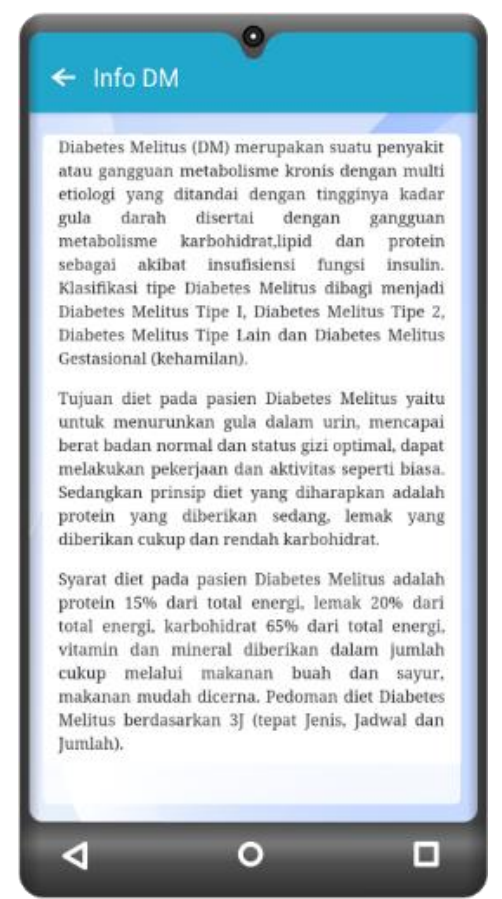

Gambar 7. Tampilan antarmuka halaman info DM

Fungsi dari tabel penukar makanan yaitu untuk merubah kandungan kalori yang dapat dikonsumsi dalam satuan kkal menjadi satuan rumah tangga, sehingga memudahkan pengguna dalam menerapkan ukuran makanannya. Tampilan antarmuka halaman tabel penukar makanan ditampilkan pada Gambar 8. 


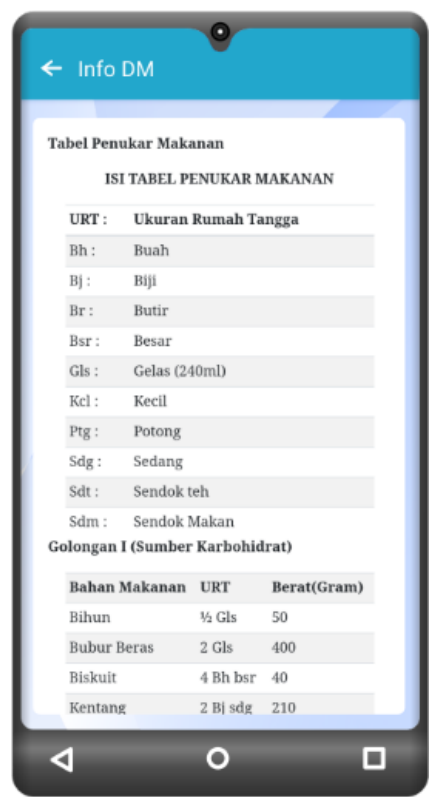

Gambar 8. Tampilan antarmuka halaman tabel penukar makanan

Menu Tentang Sistem berupa tampilan halaman sistem yang digunakan untuk menampilkan informasi mengenai sistem dan profil pengembang sistem. Tampilan halaman sistem berisi mengenai informasi sistem, foto pengembang, dan identitas pengembang sistem. Antarmuka halaman tentang sistem ditunjukkan pada Gambar 9.

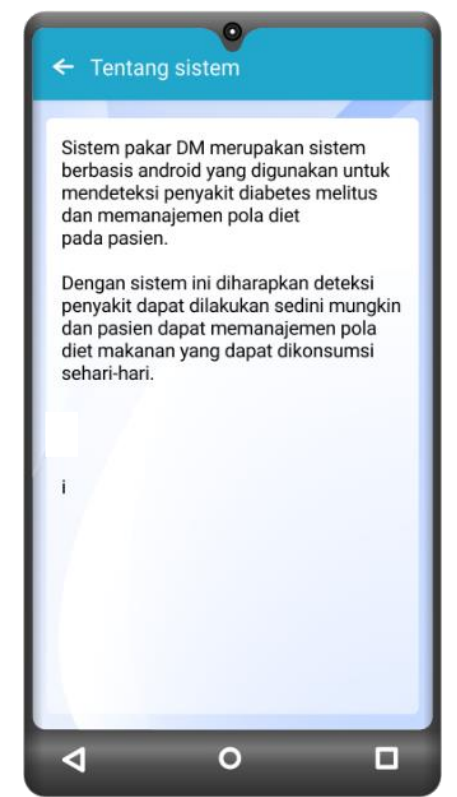

Gambar 9. Tampilan antarmuka halaman tentang sistem

Sistem pakar DM diimplementasikan pada mobile berbasis android. Setelah melaksanakan implementasi sistem pakar diabetes melitus pada mobile berbasis android, selanjutnya dilakukan tahap pengujian. Pengujian dilakukan oleh pakar dengan menguji validasi aturan produksi pada sistem. Untuk menguji aturan produksi sistem dilakukan oleh

pakar yaitu Dokter Spesialis Penyakit Dalam pada Rumah Sakit Umum Daerah M. Ashari Kabupaten Pemalang.

Pengujian yang dilakukan dengan membuat contoh kasus untuk melihat gejala yang dipilih dan menghasilkan kesimpulan penyakit diabetes melitus berdasarkan tipe penyakit yang sesuai dengan gejalanya. Pada sistem gejala-gejala disajikan dalam bentuk pertanyaan dengan dua jawaban yaitu "Ya" dan "Tidak". Setelah dipilih dari gejala yang ditampilkan maka akan muncul hasil diagnosis dan hasil persentase kemungkinan penyakitnya. Hasil pengujian sistem ditampilkan pada Tabel 5 .

Tabel 5. Hasil pengujian aturan produksi sistem

\begin{tabular}{|c|c|c|c|}
\hline $\begin{array}{l}\text { Respon- } \\
\text { den }\end{array}$ & $\begin{array}{c}\text { Hasil } \\
\text { Sistem }\end{array}$ & Hasil Pakar & Ket. \\
\hline Test 1 & $\begin{array}{l}\text { DM tipe } 1 \\
\text { Peluang } \\
69,23 \%\end{array}$ & $\begin{array}{l}\text { DM tipe } 1 \\
\text { Peluang } \\
69,23 \%\end{array}$ & Akurat \\
\hline Test 2 & $\begin{array}{l}\text { DM tipe } \\
\text { lain } \\
\text { Peluang } \\
66,67 \%\end{array}$ & $\begin{array}{l}\text { DM tipe } \\
\text { lain } \\
\text { Peluang } \\
66,67 \%\end{array}$ & Akurat \\
\hline Test 3 & $\begin{array}{l}\text { DM tipe } 2 \\
\text { Peluang } \\
61,54 \%\end{array}$ & $\begin{array}{l}\text { DM tipe } 2 \\
\text { Peluang } \\
61,54 \%\end{array}$ & Akurat \\
\hline Test 4 & $\begin{array}{l}\text { DM tipe } \\
\text { gestasional } \\
\text { Peluang } \\
75 \%\end{array}$ & $\begin{array}{l}\text { DM tipe } \\
\text { gestasional } \\
\text { Peluang } \\
75 \%\end{array}$ & Akurat \\
\hline Test 5 & $\begin{array}{l}\text { Diabetes } \\
\text { melitus } \\
\text { gestasional } \\
\text { Peluang } \\
66,67 \%\end{array}$ & $\begin{array}{l}\text { Diabetes } \\
\text { melitus } \\
\text { gestasional } \\
\text { Peluang } \\
66,67 \%\end{array}$ & Akurat \\
\hline Test 6 & $\begin{array}{l}\text { DM tipe } 2 \\
\text { Peluang } \\
69,23 \%\end{array}$ & $\begin{array}{l}\text { DM tipe } 2 \\
\text { Peluang } \\
61,54 \%\end{array}$ & $\begin{array}{l}\text { Tidak } \\
\text { akurat }\end{array}$ \\
\hline Test 7 & $\begin{array}{l}\text { Tidak } \\
\text { termasuk } \\
\text { penyakit } \\
\text { diabetes } \\
\text { melitus }\end{array}$ & $\begin{array}{l}\text { Tidak } \\
\text { termasuk } \\
\text { penyakit } \\
\text { diabetes } \\
\text { melitus }\end{array}$ & Akurat \\
\hline Test 8 & $\begin{array}{l}\text { DM tipe } 1 \\
\text { Peluang } \\
84,62 \%\end{array}$ & $\begin{array}{l}\text { DM tipe } 1 \\
\text { Peluang } \\
84,62 \%\end{array}$ & Akurat \\
\hline Test 9 & $\begin{array}{l}\text { Tidak } \\
\text { termasuk } \\
\text { penyakit } \\
\text { diabetes } \\
\text { melitus }\end{array}$ & $\begin{array}{l}\text { Tidak } \\
\text { termasuk } \\
\text { penyakit } \\
\text { diabetes } \\
\text { melitus }\end{array}$ & Akurat \\
\hline Test 10 & $\begin{array}{l}\text { DM tipe } \\
\text { gestasional } \\
\text { Peluang } \\
58,33 \%\end{array}$ & $\begin{array}{l}\text { DM tipe } \\
\text { gestasional } \\
\text { Peluang } \\
75 \%\end{array}$ & $\begin{array}{l}\text { Tidak } \\
\text { akurat }\end{array}$ \\
\hline Test 11 & $\begin{array}{l}\text { DM tipe } \\
\text { lain }\end{array}$ & $\begin{array}{l}\text { DM tipe } \\
\text { lain }\end{array}$ & Akurat \\
\hline
\end{tabular}




\begin{tabular}{|c|c|c|c|}
\hline $\begin{array}{c}\text { Respon- } \\
\text { den }\end{array}$ & $\begin{array}{l}\text { Hasil } \\
\text { Sistem }\end{array}$ & Hasil Pakar & Ket. \\
\hline & $\begin{array}{l}\text { Peluang } \\
83,33 \%\end{array}$ & $\begin{array}{l}\text { Peluang } \\
83,33 \%\end{array}$ & \\
\hline Test 12 & $\begin{array}{l}\text { DM Tipe } 1 \\
\text { Peluang } \\
69,23 \%\end{array}$ & $\begin{array}{l}\text { DM Tipe } 1 \\
\text { Peluang } \\
69,23 \%\end{array}$ & Akurat \\
\hline Test 13 & $\begin{array}{l}\text { Tidak } \\
\text { termasuk } \\
\text { penyakit } \\
\text { diabetes } \\
\text { melitus }\end{array}$ & $\begin{array}{l}\text { Tidak } \\
\text { termasuk } \\
\text { penyakit } \\
\text { diabetes } \\
\text { melitus }\end{array}$ & Akurat \\
\hline Test 14 & $\begin{array}{l}\text { DM tipe } \\
\text { lain } \\
\text { Peluang } \\
83,33 \%\end{array}$ & $\begin{array}{l}\text { DM tipe } \\
\text { lain } \\
\text { Peluang } \\
83,33 \%\end{array}$ & Akurat \\
\hline Test 15 & $\begin{array}{l}\text { DM tipe } 2 \\
\text { Peluang } \\
84,62 \%\end{array}$ & $\begin{array}{l}\text { DM tipe } 2 \\
\text { Peluang } \\
84,62 \%\end{array}$ & Akurat \\
\hline
\end{tabular}

Untuk menguji akurasi sistem maka digunakan persamaan 2 .

$$
\begin{aligned}
\text { Nilai akurasi } & =\frac{\text { Jumlah data akurat }}{\text { Jumlah seluruh data }} \times 100 \% \\
\text { Nilai akurasi } & =\frac{13}{15} \times 100 \% \\
\text { Nilai akurasi } & =86,67 \%
\end{aligned}
$$

Berdasarkan hasil pengujian, akurasi sistem pakar tersebut yaitu $86,67 \%$. Hasil pengujian menunjukkan bahwa sistem termasuk baik dalam menyusun aturan produksi dari logika pakar. Diagnosis pada sistem ini dilakukan hanya untuk pendeteksian awal pada pengguna, tidak dijadikan sebagai acuan utama untuk mendiagnosis pengguna termasuk pada penyakit diabetes melitus. Diagnosis lanjut harus dilakukan yaitu pengujian cek darah pada laboratorium untuk memastikan hasil yang lebih mendetail.

Setelah sistem pakar tersebut dilakukan transfer produksi yang ditunjukkan dengan memperbanyak produksi yaitu ditunjukkan dengan instal sistem pakar ini pada beberapa perangkat bergerak dengan platform android. Hal ini bertujuan untuk membuat cadangan sistem pakar, sehingga jika terdapat perbaikan atau penambahan pengetahuan pakar dapat dilakukan dengan menambahkan basis data yang baru. Tahapan yang terakhir adalah operasi yang ditunjukkan dengan tahap pemeliharaan dan evaluasi. Pemeliharaan sistem pakar ini dilakukan ketika terdapat pembaharuan pengetahuan pakar atau basis data.

\section{KESIMPULAN}

Dengan menggunakan metode forward chaining yang telah diterapkan pada sistem pakar untuk diagnosis penyakit diabetes melitus dengan sistem operasi android diperoleh bahwa sistem pakar tersebut dapat digunakan untuk mendiagnosis diabetes melitus sedini mungkin. Sistem juga dapat menentukan klasifikasi dari jenis penyakit diabetes melitus yang diderita oleh pasien dan menentukan persentase kemungkinan terjadinya penyakit. Pengujian dilakukan oleh pakar yaitu Dokter Spesialis Penyakit Dalam Rumah Sakit Umum Daerah Kabupaten Pemalang dengan hasil akurasi sistem 86,67\%. Hasil tersebut menyatakan bahwa sistem diagnosis penyakit diabetes melitus pada pasien sudah sesuai alur rekomendasi pakar.

\section{DAFTAR PUSTAKA}

[1] S. Of and M. Carediabetes, "Updates to the Standards of Medical Care in Diabetes-2018," Diabetes Care, vol. 41, no. 9, pp. 2045-2047, 2018, doi: $10.2337 /$ dc18-su09.

[2] A. Harum, T. Larasati, and R. Zuraida, "Hubungan diet serat tinggi dengan kadar HbA1c pasien DM tipe 2 di RSUD DR.H. Abdul Moeloek Provinsi Lampung," Med. J. lampung Univ., vol. 2, no. 4, pp. 79-87, 2013.

[3] J. Ahmad and D. Rafat, "HbA1c and iron deficiency: A review," Diabetes Metab. Syndr. Clin. Res. Rev., vol. 7, no. 2, pp. 118-122, 2013, doi: 10.1016/j.dsx.2013.02.004.

[4] B. Raditiya and M. Aditya, "Penatalaksanaan diabetes melitus tipe 2 dengan hiperkolesterolemia pada seorang pria usia 60 tahun dengan pendekatan kedokteran keluarga," J Medula Unila, vol. 5, no. 2, pp. 9-17, 2016.

[5] A. B. Evert et al., "Nutrition therapy recommendations for the management of adults with diabetes," Diabetes Care, vol. 37, no. SUPPL.1, pp. 120-143, 2014, doi: 10.2337/dc14S120.

[6] J. L. Sievenpiper, C. B. Chan, P. D. Dworatzek, C. Freeze, and S. L. Williams, "Nutrition Therapy," Can. J. Diabetes, vol. 42, pp. S64-S79, 2018, doi: 10.1016/j.jcjd.2017.10.009.

[7] I. Aritonang, Manejemen Asuhan Gizi. Yogyakarta.: Leutikabooks, 2017.

[8] R. Meza-Palacios, A. A. Aguilar-Lasserre, E. L. Ureña-Bogarín, C. F. Vázquez-Rodríguez, R. Posada-Gómez, and A. Trujillo-Mata, "Development of a fuzzy expert system for the nephropathy control assessment in patients with type 2 diabetes mellitus," Expert Syst. Appl., vol. 72, no. 1, pp. 335-343, 2017, doi: 10.1016/j.eswa.2016.10.053.

[9] F. Başçiftçi and Ö. F. Hatay, "Reduced-rule based expert system by the simplification of logic functions for the diagnosis of diabetes," Comput. Biol. Med., vol. 41, no. 6, pp. 350-356, 2011, doi: 10.1016/j.compbiomed.2011.03. 012. 
[10] J. C. dan G. D. R. Giarratano, Expert Systems: Principle and Programming, 4th Edition. Boston: Thomson Course Technology, 2004.

[11] K. R. Hole and V. S. Gulhane, "Rule-Based Expert System for the Diagnosis of Memory Loss Diseases," IJISET-International J. Innov. Sci. Eng. Technol., vol. 1, no. 3, pp. 80-83, 2014, [Online]. Available: www.ijiset.com.

[12] P. P. Brzan, E. Rotman, M. Pajnkihar, and P. Klanjsek, "Mobile Applications for Control and Self Management of Diabetes: A Systematic Review," J. Med. Syst., vol. 40, no. 9, 2016, doi: 10.1007/s10916-016-0564-8.

[13] M. Singh and N. Jain, "Design and Validation of Android Based Wireless Integrated Device for Ubiquitous Health Monitoring," Wirel. Pers. Commun., vol. 84, no. 4, pp. 3157-3170, 2015, doi: 10.1007/s11277-015-2792-5.

[14] O. Oluwagbemi, F. Oluwagbemi, and C. Ughamadu, "Android Mobile Informatics Application for some Hereditary Diseases and Disorders (AMAHD): A complementary framework for medical practitioners and patients," Informatics Med. Unlocked, vol. 2, pp. 38-69, 2016, doi: 10.1016/j.imu.2016.03. 001.
[15] D. Derisma and M. H. Saputra, "Prototype Sistem Monitoring Kesehatan Terintegrasi dengan Keluaran Pada Smartphone Android," Komputika J. Sist. Komput., vol. 9, no. 1, pp. 3541, 2020, doi: 10.34010 /komputika.v9i1.2785.

[16] R. Agarwal and M. Tanniru, "Systems development life-cycle for expert systems," Knowledge-Based Syst., vol. 3, no. 3, pp. 170-180, 1990, doi: 10.1016/0950-7051(91)90029-2.

[17] R. Prasetyo, W. Dwi, Wahyudi, "Sistem pakar diagnosis penyakit ternak sapi menggunakan metode forward chaining berbasis website responsif: expert system for diagnosing cattle diseases using forward chaining method based on responsive website," Jurnal Teknologi dan Terapan Bisnis, vol. 2, no. 1, pp. 13-21, 2019, doi: 10.5281/jttb.v2i1.45. 